\title{
Retentions of nitrogen and minerals by babies 1 week old
}

\author{
By JEAN E. SLATER \\ Medical Research Council Department of Experimental Medicine, \\ University of Cambridge
}

(Received I8 fuly I960--Revised I9 October I960)

Nearly 90 years ago, Bunge (I874) suggested that the composition of milk is adapted to the growth of the young of each particular species. Thus, the composition of cow's milk is suited to the needs of the calf, which doubles its birth weight in 6 weeks. It might be expected, therefore, that the human baby fed on cow's milk would gain weight more rapidly than the baby having its own mother's milk. In a recent review of the literature Aitken \& Hytten (I960) commented on the difficulties of making a fair comparison between the weight gains of breast-fed and artificially fed babies. The influence of other factors such as the supply of breast milk, the calorific value of the various cow's-milk preparations and the hygienic conditions have to be taken into account. Many preparations made from whole or evaporated cow's milk with added sugar, particularly those used in America 10-30 years ago, provided more calories per $100 \mathrm{ml}$ than breast milk, and there is evidence that babies having these milk mixtures were heavier than babies of the same age receiving breast milk (Nelson, 1930; Gordon \& Levine, 1944; Frost \& Jackson, I951). Present-day milk mixtures commonly used in Britain are prepared from dried whole cow's milk with the addition of lactose or other sugar, and when reconstituted according to the manufacturers' instructions, have calorific values almost the same as breast milk. The weight gains of breast-fed babies and those receiving such cow's-milk preparations have recently been shown to be essentially the same during the first 3 months after birth (Levin, Mackay, Neill, Oberholzer \& Whitehead, 1959).

The proportions of nitrogen and most minerals are greater in reconstituted cow'smilk mixtures than in breast milk, so if similar volumes of milk are taken, babies receiving cow's-milk preparations will necessarily ingest more of these constituents than breast-fed babies. The retention of $\mathrm{N}$ by babies during the ist year of life has been studied by many workers including Nelson (1930), Rominger \& Meyer (I93 I), Jeans \& Stearns (1933) and Fomon \& May (1958), and there seems to be no doubt that an increased intake results in an increased retention of $\mathrm{N}$, and the same is true for the retention of mineral constituents (Rominger \& Meyer, 1927; Jeans \& Stearns, 1933; Stearns, I939). Some of these studies were continued until the children were a year old, but none covers the early postnatal period. Fomon \& May (1958) studied the $\mathrm{N}$ retention of four babies under 2 weeks of age, but no data concerning the mineral retentions of newborn babies receiving only breast milk or a cow's-milk preparation have been found in the literature.

In rapidly growing newborn animals such as the piglet and the puppy, more than 
$75 \%$ of the dietary intake of the cellular constituents nitrogen, potassium and phosphorus are retained for purposes of growth (McCance \& Widdowson, 1956; 1958a), and growth is of far more importance than the functionally immature kidneys in maintaining the stability of the internal environment. The neonatal period is a time of intense anabolism, and although the human baby does not grow as fast as these animals, the relative growth rate is normally greater shortly after birth than it ever is again. The human baby, however, unlike the newborn of other species, is often fed on milk providing more $\mathrm{N}, \mathrm{K}, \mathrm{P}$ and $\mathrm{Ca}$ than the milk designed for it by nature. If the amounts of the various dietary constituents in breast milk are perfectly adjusted to provide for the needs of growth and development so that the end-products requiring excretion are well within the capacity of the immature kidneys, how does the newborn baby deal with the excesses from cow's-milk preparations? It was with this question particularly in mind that I undertook the present investigation.

\section{EXPERIMENTAL}

\section{Subjects}

Twenty-two normal full-term baby boys have been included in the main investigation and ten more in a subsidiary study. They were all born at the Maternity Hospital, Mill Road, Cambridge, and there had been no complications during pregnancy or delivery. Inquiries were not made about the mother's dietary history, but all the mothers were in good health, and had no record of any nutritional insufficiency.

Of the twenty-two babies in the main study, thirteen were fully breast-fed and nine had had no food other than a cow's-milk preparation since birth; no babies receiving both breast milk and cow's milk were included. The cow's-milk mixture used was made from dried whole cow's milk with added lactose, and contained 528 i.u. vitamin $\mathrm{D} /$ roo $\mathrm{g}$ dry powder. The metabolic-balance study was generally begun at the first feed on the 6th day, i.e. $5 \times 24 \mathrm{~h}$ from the time of delivery, or the feed nearest to it. It was the original intention to study each infant for 3 complete days $(6,7$ and 8$)$, but for various reasons several of the studies had to be discontinued at the end of the 2nd day. Seven breast-fed and six bottle-fed babies were studied for 3 days and the remainder for 2 days. Throughout the investigation the babies remained in the ward with their mothers and were only removed to the nursery during rest periods and at night.

The birth weights ranged from $2 \cdot 54$ to $4 \cdot 23 \mathrm{~kg}$ and the mean weight during the test period was $3.4 \mathrm{~kg}$ for the breast-fed babies and $3.6 \mathrm{~kg}$ for the bottle-fed babies. The mean weight of the bottle-fed babies at birth $(3.7 \mathrm{~kg})$ was slightly greater than that of the breast-fed babies $(3.4 \mathrm{~kg})$, but the mean daily weight gain during the test period was a little greater for the breast-fed babies $(35 \mathrm{~g})$ as compared with $25 \mathrm{~g}$ for those that received the cow's-milk preparation.

All ten babies in the subsidiary study were fully breast-fed. They were given $120 \mathrm{mg}$ $\mathrm{P}$ as a I :4 mixture of $\mathrm{KH}_{2} \mathrm{PO}_{4}$ and $\mathrm{Na}_{2} \mathrm{HPO}_{4}$ dissolved with a little water in a feeding bottle on the $5^{\text {th }}, 6$ th and 7 th days after birth. Urine was collected from each baby for $24 \mathrm{~h}$ on the 7 th day. 


\section{Metabolic-balance procedure}

\section{Measurement of the milk intake and preparation for analysis}

Breast-fed babies. The mothers fed their babies in the normal way under supervision. The volume of breast milk ingested was measured by test weighing the baby at each feed on scales which had previously been shown to be accurate to $\pm 3 \mathrm{~g}$. A small sample of breast milk was expressed by each mother at the beginning and end of alternate feeds, and the samples for the whole of the balance period were pooled for analysis.

Bottle-fed babies. Enough milk powder was reconstituted to last $24 \mathrm{~h}$ and stored in the refrigerator. The powder was weighed out accurately to the nearest $\mathrm{g}$, mixed with boiling distilled water, cooled and made to volume in the proportion of $60 \mathrm{~g}$ powder to $400 \mathrm{ml}$ reconstituted milk. The volume ingested at each feed was measured by weighing the bottle to the nearest $g$ at the beginning and end of each feed. The preparation was analysed as a dry powder, and the amount of each constituent ingested was calculated, a uniform composition of the reconstituted milk being assumed. From time to time a check was made on the composition of the reconstituted mixture and it was found to be in good agreement with the calculated composition.

Regurgitation. Nylon seersucker lined with Polythene was used to collect any regurgitated milk. An oblong piece of white nylon seersucker, $18 \times 12$ in., was folded three times, stitched down the sides and a piece of Polythene was slipped between the folds. This bib was securely tied round the baby's neck to collect any regurgitated milk during a feed. A similar arrangement was made for the cot to collect regurgitation between feeds; a piece of Polythene was put over the head end of the cot sheet and covered with a square of white nylon seersucker. With one or two exceptions, it was found that breast-fed babies rarely regurgitated between feeds, but nylon and Polythene covers were still used in the cot as a precautionary measure. Any milk regurgitated during the feed was discarded before the final weighing of the breast-fed babies, but it was carefully collected from the bottle-fed babies.

At the end of the balance period all the bibs and cot covers from each baby were washed several times in warm distilled water in an enamel tray. The total washings were acidified with Io $\mathrm{ml}$ conc. $\mathrm{H}_{2} \mathrm{SO}_{4}$ and evaporated down to a suitable volume in a beaker on a heated sand tray. Portions of this acid digest were used for the estimation of $\mathrm{N}$ and mineral constituents. The amount of each constituent regurgitated was subtracted from the measured intake of each baby.

Urine samples. At the beginning of the balance period the buttocks, groins, scrotum and penis of the baby were washed to remove any traces of dusting powder or cream, and dried with a soft towel. The urine collector consisted of a small funnel-like tube of glass, $\frac{1}{2}$ in. across at the open end, attached to a Polythene tube draining down into a collecting bottle, which was supported in an upright position between the mattress and the side of the cot, and contained toluene. The funnel fitted over the penis with a circle of thin rubber, and was attached to the scrotum with waterproof adhesive strapping. There was an air hole in the rubber connexion to allow free drainage of the urine. Each $24 \mathrm{~h}$ collection was measured to the nearest $\mathrm{ml}$ and stored separately for analysis. 
Faecal samples. Washable white nylon seersucker squares were found to be ideal for the collection of faecal material. They were folded round the infant in the same way as an ordinary napkin, and plastic 'Paddi-pants' were put over the top. The nylon napkins were changed frequently since they were not very absorbent.

Carmine marker. Carmine powder $(0 \cdot 25 \mathrm{~g})$ was mixed with water in a feeding bottle and given just before the first feed of the balance period, and again before the first feed after the test period was completed. Stools were collected from the first appearance of the pink colour until the final marker came through.

Soiled napkins for the whole of the test period were washed in distilled water in the same way as the nylon bibs, and an acid digest was prepared by the addition of $15 \mathrm{ml}$ conc. $\mathrm{H}_{2} \mathrm{SO}_{4}$ to the washings.

Blood sample. A small sample of blood was collected by heel prick from five breastfed and four bottle-fed babies on the 7 th day after birth and used for the estimation of urea.

\section{Chemical methods}

$\mathrm{N}$ was determined by the micro-Kjeldahl technique, urea by the method of Lee $\&$ Widdowson (1937), creatinine by a modification of Folin's method as described by Hawk, Oser \& Summerson (1954, p. 800) and uric acid as described by King (1946). Lactose in the milks was measured by the Munson-Walker method, as described by the Association of Official Agricultural Chemists (1950) after deproteinization, and the fatty acids were determined gravimetrically by a modification of von Lieberman \& Székely's (1898) method. Chloride in the milk and urine samples was estimated by Volhard's method as described by Hawk et al. (1954, p. 955).

Samples of the milks, urines and the acid digests of the regurgitated milk and faeces were ashed at $45^{\circ}$ and the ash was extracted by the procedure of McCance \& Shipp (1933). $\mathrm{Ca}, \mathrm{Mg}$ and $\mathrm{P}$ were estimated in the acid extract of the ash as described by Economou-Mavrou \& McCance (1958), and $\mathrm{K}$ by a modification of the Kramer \& Tisdall (1921) method in which the precipitation was carried out overnight at $0^{\circ}$, and the nitrite in the precipitate measured by reaction with ceric sulphate. $\mathrm{Na}$ was determined in the ash extract by flame photometry after preliminary treatment to remove interfering substances, as described by Widdowson \& Southgate (1959).

\section{Composition of the milks}

The mean values for the various constituents of breast milk have been compared with those of the reconstituted milk powder in Table I. All constituents, except fat, were more concentrated in the cow's-milk preparation; the proportion of $\mathrm{N}$ was approximately one and a half times, of $\mathrm{K}$ almost twice, and of $\mathrm{Mg}$ three times that in breast milk. The amount of $\mathrm{Ca}$ in the reconstituted milk powder was four times and the amount of $\mathrm{P}$ five times the amount in the same volume of breast milk, and the ratio $\mathrm{Ca}: \mathrm{P}$ was $\mathrm{r} \cdot 33$ in the cow's-milk preparation and $\mathrm{r} \cdot 64$ in the average breast milk. The proportion of $\mathrm{Cl}$ was also a little higher in the cow's-milk preparation, but there was very little difference in the amount of $\mathrm{Na}$. 
RESULTS

\section{Composition of the regurgitated milk}

The constituents in the regurgitated milk from the bottle-fed babies were not present in the same proportions as in the reconstituted milk, and accounted for a variable percentage of the uncorrected intake. The proportion of $\mathrm{N}$ varied from 0.2 to $2.5 \%$ and of $\mathrm{Ca}$ from 0.2 to $\mathrm{I} \cdot 3 \%$ of the intake, which shows the fallacy of deducting an approximate volume of milk from the measured intake. In some instances the amount of each constituent regurgitated was so small that it made little difference to the total balance, but in others it was sufficiently large to give a false impression of the difference between the retentions from the two types of milk if no correction was made for it.

\section{Time taken for the carmine marker to appear}

The time between giving the carmine and its appearance in the stools was noted for sixteen babies. There was wide variation, but each baby tended to behave in a characteristic way; two breast-fed babies passed their markers in 7 or $8 \mathrm{~h}$ on each occasion, whereas another only passed stools twice during the balance period and the markers took 24 and $28 \mathrm{~h}$ to come through. On the whole the first marker came through more quickly in the babies having cow's milk, which can probably be explained by the looser stools these babies passed on the 6th-7th days after birth. By the 8th-9th days, the stools were more formed and the average time for the second marker was similar in both groups of babies.

Table r. Comparison between the compositions (per 100 $\mathrm{ml}$ ) of breast milk and reconstituted milk powder

\begin{tabular}{|c|c|c|}
\hline & Breast milk* & $\begin{array}{l}\text { Reconstituted } \\
\text { milk powder }\end{array}$ \\
\hline Calories (kcal) & 75 & 72 \\
\hline Total solids (g) & $13.9 \pm 1.21$ & 14.7 \\
\hline$N(g)$ & $0.33 \pm 0.05$ & 0.44 \\
\hline Fat $(g)$ & $4 \cdot 17 \pm 1 \cdot 27$ & $2 \cdot 58$ \\
\hline Lactose (g) & $7.37 \pm 0.9$ & $9 \cdot 56$ \\
\hline Ash (g) & $0.27 \pm 0.05$ & 0.66 \\
\hline $\mathrm{K}(\mathrm{mg})$ & $70 \cdot 5 \pm I I .2$ & 132 \\
\hline $\mathrm{Na}(\mathrm{mg})$ & $40.6 \pm 17 \cdot 2$ & $43 \cdot 3$ \\
\hline $\mathrm{Cl}(\mathrm{mg})$ & $69.3 \pm 28.9$ & 93.5 \\
\hline$P(\mathrm{mg})$ & $16 \cdot 3 \pm 3 \cdot 4$ & $76 \cdot 2$ \\
\hline $\mathrm{Ca}(\mathrm{mg})$ & $26 \cdot 7 \pm 6 \cdot 0$ & IOI \\
\hline $\mathrm{Mg}(\mathrm{mg})$ & $2.60 \pm 0.61$ & $7 \cdot 95$ \\
\hline Ratio, Ca:P & $I \cdot 64$ & $I \cdot 33$ \\
\hline
\end{tabular}

* Mean values with standard deviations for milk from eighteen mothers.

\section{Calorie intakes}

The mean volume of milk taken by the breast-fed babies amounted to $129 \mathrm{ml} / \mathrm{kg}$ day, and by the bottle-fed babies to $134 \mathrm{ml} / \mathrm{kg}$ day. The reconstituted cow's-milk preparation had a slightly lower calorific value than the mean for the samples of breast milk (Table I), but the calorie intake of the bottle-fed babies $(96 \mathrm{kcal} / \mathrm{kg}$ day) was 
almost the same as the intake of the breast-fed babies $(97 \mathrm{kcal} / \mathrm{kg}$ day). Seven of the breast-fed babies had regained their birth weight by the 8th day as compared with four of the bottle-fed babies, and the mean gain in weight over the days of the experiment was slightly greater for the babies that were breast-fed.

\section{Intakes, excretions and retentions of dietary constituents}

The mean values for the amounts of $\mathrm{N}$ and mineral constituents ingested, absorbed and retained by the breast-fed and bottle-fed babies are shown in Table 2.

Nitrogen. The proportion of the intake of $\mathrm{N}$ absorbed $(80-90 \%)$ was similar to that found in adults (Atwater \& Benedict, 1899) but, unlike adults, who are usually in approximate $\mathrm{N}$ balance, or older children who retain only a small proportion of their $\mathrm{N}$ intake, the babies retained half of their intake of $\mathrm{N}$ from both types of milk. The bottlefed babies ingested $200 \mathrm{mg} / \mathrm{kg}$ day more than the breast-fed babies, and retained $127 \mathrm{mg} / \mathrm{kg}$ day more; this increased retention from a higher intake is in accordance with the results of other investigations on older babies (Rominger \& Meyer, I93 I; Jeans, Stearns, McKinley, Goff \& Stinger, 1936; Fomon \& May, 1958).

The mean concentration of urea in the blood of the bottle-fed babies $(37.9 \mathrm{mg} /$ $100 \mathrm{ml}$ ) was more than twice that of the babies receiving only breast milk $(17.5 \mathrm{mg}$ ) $100 \mathrm{ml}$ ), which would account for some of the 'extra' $\mathrm{N}$ retained, but by no means all of it. If all the 'extra' $N$ had been converted into urea, the concentration in the body fluids would have reached a pathological level before the babies were I week old.

The babies having the cow's-milk preparation excreted more $\mathrm{N}$ in their urine (22I $\mathrm{mg} / \mathrm{kg}$ day) than the breast-fed babies (I $7 \mathrm{mg} / \mathrm{kg}$ day). Table 3 shows the mean daily excretions of $\mathrm{N}$ in the form of urea, creatinine and uric acid by several babies on the 7 th day after birth. The breast-fed babies excreted on the average $77 \mathrm{mg}$ and the bottle-fed babies I $8 \mathrm{I} \mathrm{mg}$ urea $\mathrm{N} / \mathrm{kg}$ day, and these amounts represent different proportions of the total urinary excretion of $\mathrm{N}$ for the two groups of babies, but in both it was lower than the average value for an adult $(85 \pm 3.7 \%$ ) (Widdowson, Dickerson \& McCance, 1958). The excretions of creatinine $\mathrm{N}$ and uric acid $\mathrm{N}$ in the urine did not vary with the type of milk, but accounted for a smaller percentage of the total $\mathrm{N}$ excreted by the babies receiving cow's milk, which is probably associated with the greater proportion of urea $\mathrm{N}$.

Potassium. The amount of $\mathrm{K}$ in the samples of breast milk varied between 45 and $88 \mathrm{mg} / 100 \mathrm{ml}$, and hence there was considerable variation in the amount ingested by the breast-fed babies; the mean value was $88.5 \mathrm{mg} / \mathrm{kg}$ day, which was half the mean intake of the babies receiving cow's milk. As with $\mathrm{N}$, both groups of babies absorbed a high proportion of their intake and retained approximately half; the breast-fed babies retained $46.9 \mathrm{mg}$ and the bottle-fed babies $79.4 \mathrm{mg} / \mathrm{kg}$ day. No allowance has been made for the loss of $\mathrm{K}$ through the skin. Swanson \& Iob (I933) reported that as much as $30 \%$ of the $\mathrm{K}$ apparently retained by babies $2-24$ weeks old was lost in this way. This estimate seems rather high, and may be due to the difficulties of collecting sweat from young babies and the high environmental temperatures of American nurseries. Another factor which must be taken into account is the normal wide variation of electrolyte balance over a period of days noted by Gamble, Wallace, Eliel, 


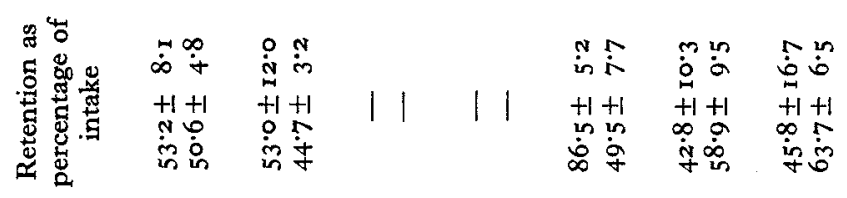

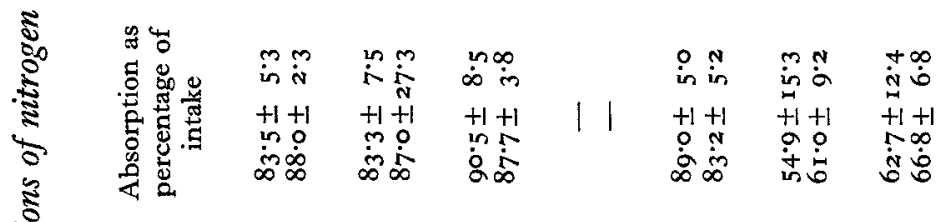

宽

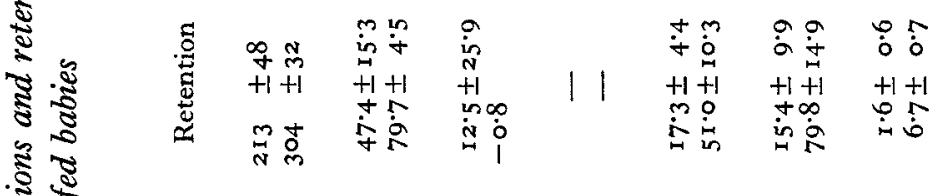

帘

$\frac{\sqrt{3}}{3} \cdot \frac{3}{2}$

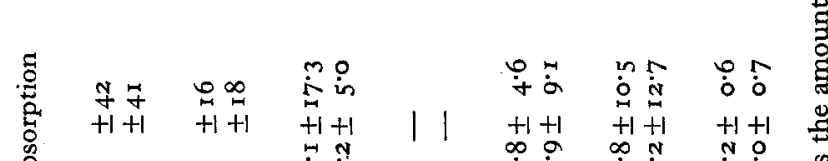

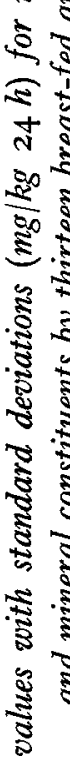

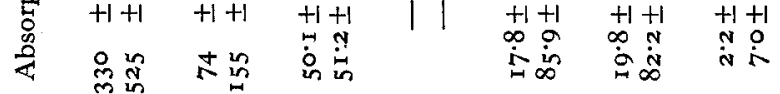

平

兽

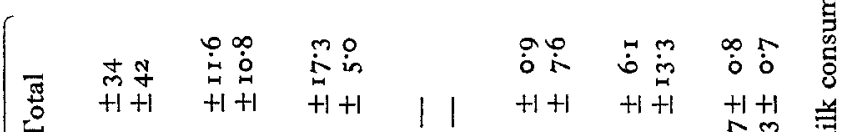

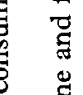

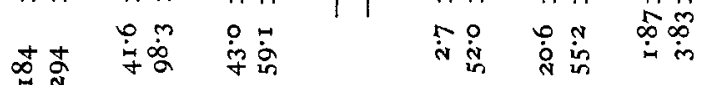

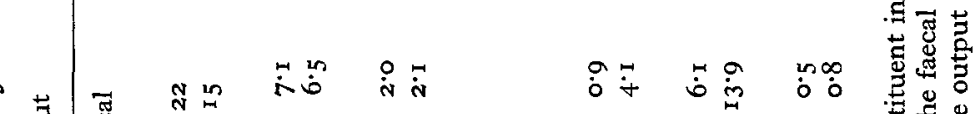

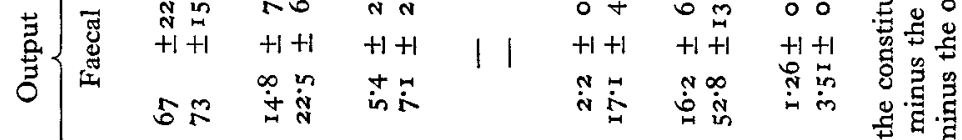

出䊁

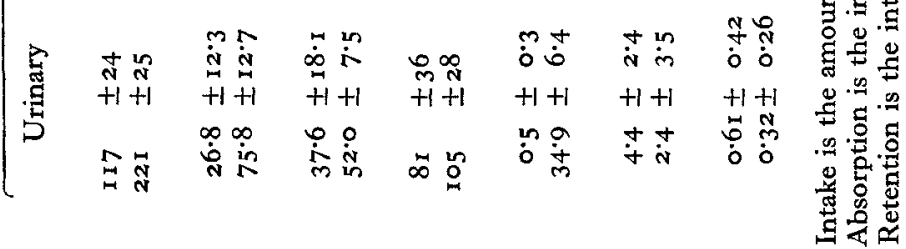

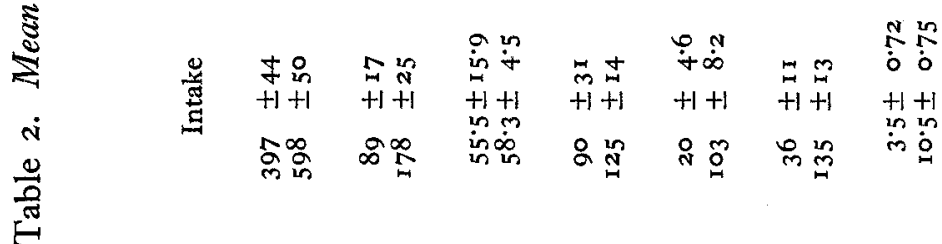

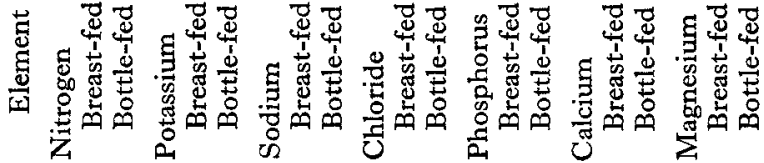


Holliday, Cushman, Appleton, Shenberg \& Piotti (195I). However, despite the losses through the skin and the oscillation of electrolyte excretion, the babies having cow's milk must have retained more $\mathrm{K}$ on an average than those having breast milk.

The amount of $\mathrm{K}$ in the serum was not measured, but there is no evidence that bottlefed babies have a pathologically high concentration (Hoffman, Parmelee \& Grossman, 1949), so the 'extra' amount must have been used for the purposes of growth.

Sodium and chloride. Individual breast-fed babies varied considerably in their intakes, excretions and retentions of $\mathrm{Na}$, but on the average there was a small positive retention; the bottle-fed babies on the other hand were in approximate 'balance'. No measurements were made of the faecal $\mathrm{Cl}$ or of the losses of $\mathrm{Na}$ and $\mathrm{Cl}$ through the skin, but from the values for the urinary excretions it seems that both groups of infants would have had small negative $\mathrm{Cl}$ balances.

Table 3. Mean values for urinary excretions of urea, creatinine and uric-acid nitrogen by breast-fed and bottle-fed babies

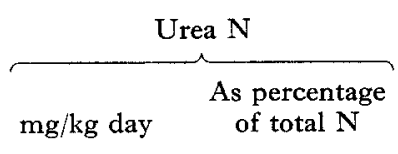

$77(8)$

I 8 I (6)

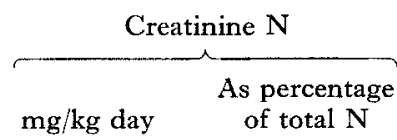

Breast-fed babies

$64 \cdot 2 \quad I \cdot 7(8) \quad I \cdot 4$

Bottle-fed babies

I.7 (8) $\quad 0.7$

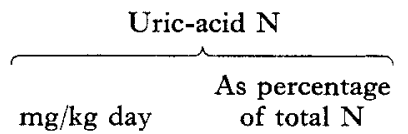

$3 \cdot 9(5)$

$3 \cdot 2$

$3 \cdot 6(4)$

I 5

Figures in parentheses are the numbers of babies.

Phosphorus. The amount of $\mathrm{P}$ in the cow's-milk preparation was almost five times the amount in the average breast milk; hence per kg per day the bottle-fed babies ingested five times as much as the breast-fed babies. As found with other cellular constituents, $\mathrm{N}$ and $\mathrm{K}$, both groups of babies absorbed more than $80 \%$ of their dietary $\mathrm{P}$. The urinary excretion by the breast-fed babies was very small, $0.5 \pm 0.3 \mathrm{mg} / \mathrm{kg}$ day, which is in agreement with the findings of other workers (McCance \& von Finck, 1947; Dean \& McCance, I948). The bottle-fed babies excreted $34 \cdot 9 \pm 6 \cdot 4 \mathrm{mg} / \mathrm{kg}$ day in their urine and retained only half their intake of $P$, but this was still three times the amount retained by the breast-fed babies.

The concentration of $\mathbf{P}$ in the serum of bottle-fed babies is known to be higher than in the serum of breast-fed babies (Gardner, Maclachlan, Pick, Terry \& Butler, 1950; Smith, 1959) and on the 7 th day after birth Widdowson \& McCance (1959) found a mean value of $9.0 \mathrm{mg} / 100 \mathrm{ml}$ for some of the bottle-fed babies of the present series, compared with $6.8 \mathrm{mg} / 100 \mathrm{ml}$ for the breast-fed babies. This difference of $2 \cdot 2 \mathrm{mg} /$ roo $\mathrm{ml}$, however, could account for only a very small proportion of the 'extra' $\mathrm{P}$ retained by the bottle-fed babies and they presumably incorporated the remainder into the soft tissues and bones.

Calcium. The bottle-fed babies were taking in four times as much $\mathrm{Ca}$ as those having breast milk, and absorbed four times as much. It must be noted that the bottle-fed babies were taking in small amounts of vitamin D (70-100 i.u./kg) each day, which 
may have increased their intestinal absorption of $\mathrm{Ca}$ as compared with the breast-fed babies who received no vitamin supplements during the study period. The babies having cow's milk retained five times as much $\mathrm{Ca}$ as the breast-fed babies, and as a percentage of the intake they retained $59 \%$ compared with $40 \%$. This greater percentage retention from cow's-milk preparations has been noted for older babies by Rominger \& Meyer (1927), and Stearns (1939).

Perhaps the most unexpected feature of these results is the urinary excretion. The average breast-fed baby excreted $4 \cdot 43 \pm 2 \cdot 42 \mathrm{mg} / \mathrm{kg}$ day in the urine, whereas the bottlefed babies, who absorbed over $80 \mathrm{mg} / \mathrm{kg}$ day, excreted only $2 \cdot 4 \pm 3.53 \mathrm{mg} / \mathrm{kg}$ day. One bottle-fed baby had an exceptionally high urinary $\mathrm{Ca}$, and when it was excluded from the mean, the value was only $\mathrm{I} \cdot 16 \pm 0 \cdot 47 \mathrm{mg} / \mathrm{kg}$ day, which is significantly lower than the value for breast-fed babies. Calculations made from the data of Benjamin, Gordon \& Marples (1943) for premature babies I3-2I days old show that the babies having cow's-milk preparations also excreted slightly less $\mathrm{Ca}$ in their urine $(4.6 \mathrm{mg})$ each day than those having breast milk $(5.6 \mathrm{mg})$; the $\mathrm{Ca}$ intakes were 165 and $56 \mathrm{mg} / \mathrm{kg}$ day respectively.

Magnesium. The breast-fed babies ingested $3-4 \mathrm{mg} / \mathrm{kg}$ day, and retained less than $2 \mathrm{mg} / \mathrm{kg}$ day. The urinary excretion was very variable, and on the whole seemed to be related to the proportion in the mother's milk. The bottle-fed babies ingested over Io $\mathrm{mg} / \mathrm{kg}$ day, and retained $6-7 \mathrm{mg} / \mathrm{kg}$ day, three to four times as much as the breastfed babies. Again, there was considerable variation in the individual urinary excretions but, in spite of the high intake, the excretion in the urine was less than the excretion by the breast-fed babies, $0.32 \pm 0.26$ compared with $0.61 \pm 0.42 \mathrm{mg} / \mathrm{kg}$ day.

\section{Urinary excretion of $C a, M g$ and $P$ by healthy breast-fed babies receiving additional $P$}

The results for these babies, together with the mean values for the urinary excretions of the breast-fed and bottle-fed babies in the main investigation, are shown in Table 4. The urinary excretions of $\mathrm{Ca}$ and $\mathrm{Mg}$ by the babies receiving additional $\mathrm{P}$

Table 4. Mean values with standard deviations $(m g / k g ~ 24 h)$ for urinary excretions of calcium, magnesium and phosphorus by breast-fed babies receiving additional phosphorus compared with the values for breast-fed and bottle-fed babies receiving no supplement

$\mathrm{Ca} \quad \mathrm{Mg} \quad \mathrm{P}$

Ten breast-fed babies receiving additional phosphorns
$\begin{array}{lcc}2.07 \pm I .88 & 0.19 \pm 0.15 & 20.0 \pm 4.3 \\ \text { Thirteen breast-fed babies without supplement } \\ 4.43 \pm 2.42 & 0.61 \pm 0.42 & 0.46 \pm 0.30 \\ \text { Nine bottle-fed babies without supplement } \\ 2.40 \pm 3.53 & 0.32 \pm 0.26 & 34.9 \pm 6.4\end{array}$

were lower than those of the breast-fed babies having no supplements; again, one baby had a higher excretion of $\mathrm{Ca}$ than the others, and when he was excluded from the mean, a value of $\mathrm{r} \cdot 47 \pm 0.72 \mathrm{mg}$ was obtained. These values are similar to those 
obtained for the bottle-fed babies. As with the babies in the main series, the excretion of $\mathrm{Mg}$ was very variable, $0 \cdot 2-0.32 \mathrm{mg} / \mathrm{kg}$ day. The mean value, however, was significantly lower than the mean value for the breast-fed babies previously studied $(P=0.05)$.

\section{DISCUSSION}

\section{Retention of dietary constituents in relation to growth and development}

Newborn babies, like other newborn animals, not only grow in size but also change the composition of their organs and tissues during development. If the excesses of cellular constituents and bone minerals retained by the bottle-fed babies do not lead to a more rapid gain in weight they must be used to increase the rate of chemical maturation of the soft and hard tissues of the body. It is almost impossible to get direct proof of this in man because adequate post-mortem material from babies who are known to

Table 5. Total amounts ( $g$ ) of water, nitrogen and mineral constituents in the skeletal muscle, skin and skeleton of an infant at birth and at 6 months of age

\begin{tabular}{|c|c|c|c|c|c|c|}
\hline & \multicolumn{2}{|c|}{ Skeletal muscle } & \multicolumn{2}{|c|}{ Skin } & \multicolumn{2}{|c|}{ Skeleton } \\
\hline & Newborn & At 6 months & Newborn & At 6 months & Newborn** & At 6 months* \\
\hline Weight $(\mathrm{g})$ & 870 & 1740 & 525 & 1050 & 630 & 1260 \\
\hline Water & 703 & 1370 & 444 & 725 & 401 & 775 \\
\hline $\mathbf{N}$ & $18 \cdot I$ & 50.9 & $14 \cdot 2$ & $58 \cdot 3$ & I7 & 40 \\
\hline $\mathrm{K}$ & $1 \cdot 95$ & $6 \cdot 12$ & 0.94 & $1 \cdot 82$ & - & - \\
\hline $\mathrm{Na}$ & $I \cdot 2 I$ & $2 \cdot 01$ & $I \cdot 08$ & $1 \cdot 71$ & - & 一 \\
\hline $\mathrm{Cl}$ & $r \cdot 45$ & $2 \cdot 20$ & $\mathrm{I} \cdot 27$ & $2 \cdot 76$ & - & - \\
\hline $\mathrm{P}$ & $\mathbf{1} \cdot \mathbf{2} 8$ & 3.53 & 0.53 & $I \cdot I 6$ & I 8 & 32 \\
\hline $\mathrm{Ca}$ & 0.08 & O.I I & $0.1 \mathrm{I}$ & 0.25 & $3^{8}$ & 73 \\
\hline $\mathrm{Mg}$ & $0 \cdot 16$ & 0.42 & 0.03 & 0.10 & - & - \\
\hline
\end{tabular}

* These values are based on the assumption that the composition of the femur is representative of the composition of the whole skeleton. It is probable that the figures for $\mathrm{Ca}$ are too high, for the average amount of $\mathrm{Ca}$ found in the whole bodies of full-term stillborn babies was $28 \mathrm{~g}$ (Widdowson \& Spray, 195 I).

have received only breast milk or a cow's-milk preparation during the first months of life is virtually unobtainable. Some information is available about the changes in the composition of the skeletal muscle, skin, the major organs and bone during the first months of life (Dickerson, 1959; Dickerson \& Widdowson, 1960; Widdowson \& Dickerson, I960; Dickerson, personal communication), but the babies from whom the tissues came had received both breast milk and cow's-milk preparations. The total amounts of $\mathrm{N}$ and minerals in the major tissues at birth and 6 months of age have been calculated from these data, on the assumption that skeletal muscle accounts for $25 \%$ of the weight at birth, the skin $15 \%$ and the skeleton $18 \%$ (Wilmer, 1940), and that the contribution of these major tissues to the total body-weight remains the same for the first 6 months. The results are shown in Table 5. The figures are only approximations, but they serve to demonstrate the amounts of $\mathrm{N}$ and minerals required for the growth and development of the major soft tissues and the skeleton.

Soft tissues. If the daily retention of $\mathrm{N}$ had been the same for the whole of the first 6 months as it was over the 3 days of observation $(730 \mathrm{mg} /$ day) $137 \mathrm{~g}$ would have been 
added to the body at the end of this time. It is probable, however, that the amount of $\mathrm{N}$ retained each day decreases as the baby grows older, for the six breast-fed babies studied by Fomon \& May (1958) retained $720 \mathrm{mg} /$ day at $\mathrm{I}$ month and $400 \mathrm{mg}$ at 6 months, and the total retention during the first 6 months was about $\mathrm{I}$ rog.

From the values in Table $5,100 \mathrm{~g} \mathrm{~N}$ can be accounted for by the growth and development of muscle, skin and bone, which make up $58 \%$ of the total body-weight, but this calculation does not take into account the 'vital' organs and other parts of the body. The retention from breast milk, therefore, seems hardly sufficient to enable the tissues to attain the composition shown in Table 5 , and it is probable that the tissues analysed were chemically more mature than those of babies receiving only breast milk during this period of life. Some of the 'excess' $N$ retained by the bottle-fed babies of the present series was undoubtedly katabolized to urea, but at least half was probably used for the more rapid chemical development of the organs and tissues.

The relationship between the retention of $\mathrm{N}$ and $\mathrm{K}$ during development gives some indication as to the sites of deposition. $\mathrm{N}$ is laid down without $\mathrm{K}$ in the form of collagen, particularly in skin and bone (Widdowson \& Dickerson, 1960), so the relative increase in the amount of $\mathrm{K}$ in the body is normally smaller than the increase of $\mathrm{N}$. Presumably the breast-fed babies retained sufficient $\mathrm{K}$ to meet the intracellular needs of the growing cells, and any 'extra' $\mathrm{K}$ retained by the bottle-fed babies must have increased the concentration of $\mathrm{K}$ in the cells, or there must have been an increased cell mass to accommodate the excess. Beem \& Smith (see McCance \& Widdowson, $1958 b$ ) were puzzled by the large retentions of $\mathrm{K}$ by premature babies having cow's milk; these babies did not retain a correspondingly large excess of $\mathrm{N}$, and the authors could offer no satisfactory explanation. McCance \& Widdowson (1958b) showed that newborn piglets given sow's milk with added $\mathrm{KCl}$ retained twice as much $\mathrm{K}$ as those given sow's milk alone, without a corresponding difference in the amount of $\mathrm{N}$ retained. There was a small rise in the piglets' serum $\mathrm{K}$, but most of the $\mathrm{K}$ could be accounted for by a change in the composition of the skeletal muscle. It is possible that similar changes were taking place in the muscles of the bottle-fed babies, although the process could hardly continue indefinitely.

There was considerable variation in the retentions of $\mathrm{Na}$ and $\mathrm{Cl}$ between individual babies, so that the mean values can be used only to suggest possible trends. The bottlefed babies retained more of the cellular constituents than the breast-fed babies, but probably less of the extracellular constituents $\mathrm{Na}$ and $\mathrm{Cl}$.

The skeleton. The negligible urinary excretion of $\mathrm{P}$ by breast-fed babies seems to indicate that all the dietary $P$ is utilized (Smith, r959; Widdowson \& McCance, 1959), and the 'extra' retained by the bottle-fed babies is presumably incorporated into the soft tissues and bones along with other cellular constituents and $\mathrm{Ca}$. The breast-fed babies given supplements of phosphate probably retained about one-third of the administered dose and excreted less $\mathrm{Ca}$ and $\mathrm{Mg}$ in their urine than the breast-fed babies receiving no supplement; the same has been shown to be true of strontium (Widdowson, Slater, Harrison \& Sutton, I960). No estimate of the amount of $P$ in the faeces of the babies receiving the supplement was made, so that the amount of $P$ 
retained was not known. It is suggested that the amount of $\mathrm{P}$ in breast milk is a limiting factor for the formation of bone salts, and any surplus $\mathrm{Ca}$, and probably also $\mathrm{Mg}$, must be combined as carbonate or excreted in the urine. The babies who received the cow's-milk preparation ingested more $\mathrm{P}$ and also more $\mathrm{Ca}$ and $\mathrm{Mg}$; more $\mathrm{P}$ was available for the growth and development of bone, with the result that more $\mathrm{Ca}$ and $\mathrm{Mg}$ could be utilized, and less was excreted in the urine than in the urine of the breast-fed babies.

The daily retention of $0.052 \mathrm{~g} \mathrm{Ca}$ by the breast-fed babies represents $0.2 \%$ of the total $\mathrm{Ca}$ in the full-term baby at birth (Widdowson \& Spray, I95 I) and the retention by the bottle-fed babies represents $\mathrm{I} \cdot 0 \%$. The gain in weight over the first 6 months averages about $0.6 \%$ of the birth weight each day. As the baby grows, more milk is ingested and the retention of $\mathrm{Ca}$ increases (Rominger \& Meyer, I927; Jeans et al. 1936; Duckworth \& Warnock, 1942-3). Stearns (1939) suggested some years ago that the retention of $\mathrm{Ca}$ from breast milk was insufficient for the growing skeleton to maintain the composition it had at birth, and that during the first weeks of life there must be a decrease in the percentage of $\mathrm{Ca}$ in the whole body. The present results confirm this postulate, but it seems likely that the bottle-fed babies retained enough $\mathrm{Ca}$, along with $\mathrm{P}$ and other bone minerals, to prevent the same initial decrease in the percentage of $\mathrm{Ca}$, although by Stearns's calculations the decrease was greater for bottle-fed than for breast-fed babies during the first weeks after birth. The first point on the graph drawn by Stearns (1939) relating body-weight to the amount of $\mathrm{Ca}$ in the body was from values for babies over 3 weeks old, so that the relationship during the neonatal period was not deduced from experimental evidence. The results of the present series of balance studies show that this part of her curve is almost certainly inaccurate.

The difficulties of obtaining adequate post-mortem material to compare the amount of $\mathrm{Ca}$ in the skeletons of well-nourished babies who are known to have received only breast milk or a cow's-milk preparation are almost insurmountable. Gross changes in calcification and in the development of centres of ossification can be detected by X-ray studies, but the differences between the present-day breast-fed and bottle-fed babies may never be great enough to be detected by this method. The children studied by Jeans \& Stearns (1933) for 5-50 weeks while receiving a I : I dilution of evaporated milk and corn syrup showed more rapid carpal ossification and tooth eruption than 'average' children. These changes may have been associated with the fact that the babies having evaporated milk and corn syrup grew faster in length and weight. Studies of kittens receiving additional Ca during the neonatal period indicate that the extra $\mathrm{Ca}$ increased the rate of calcification of some parts of the skeleton (Slater $\&$ Widdowson, to be published).

The babies receiving breast milk retained more $\mathrm{P}$ than $\mathrm{Ca}$, and the retention ratio of $\mathrm{Ca}: \mathrm{P}$ was 0.87 , whereas the reverse was true for the babies having cow's milk, for whom the retention ratio was $\mathrm{I}^{\cdot} 56$. Since $99 \%$ of the body $\mathrm{Ca}$ is in the skeleton, nearly all the retained $\mathrm{Ca}$ will be in the bones, and the distribution of $\mathrm{P}$ between the skeleton and the soft tissues can be calculated approximately from the $\mathrm{Ca}: \mathrm{P}$ ratio of the skeleton. Table 5 shows that the $\mathrm{Ca}: \mathrm{P}$ ratio of the skeleton at birth is $2 \cdot 2$, and at 6 months after birth is $2 \cdot 3$, so there is very little change during this time. From this 
ratio it can be calculated that the amount of $P$ retained in the skeleton of the breast-fed babies along with $15.3 \mathrm{mg}$ Ca was $6.6 \mathrm{mg}$ each day, leaving $17.5-6.6 \mathrm{mg}=10.9 \mathrm{mg} \mathrm{P}$ for the soft tissues. The bottle-fed babies retained $79.4 \mathrm{mg} \mathrm{Ca}$, which would account for $34.5 \mathrm{mg} P$ deposited in the skeleton and leave $5 \mathrm{I}^{\cdot} \cdot 0-34^{\cdot} 5 \mathrm{mg}=\mathrm{I} 6.5 \mathrm{mg} \mathrm{P}$ for the soft tissues. Thus, the amount of $P$ that would have been available for the growth and development of the soft tissues, even if the rise in serum $\mathrm{P}$ of the bottle-fed babies is allowed for, was higher in this group. This finding is in line with the other findings of an increased retention of $\mathrm{N}$ and $\mathrm{K}$ by these babies, for all three of these elements would be necessary for the more rapid maturation of the soft tissues. Stearns (1939), in a discussion of the retentions of $\mathrm{Ca}$ and $\mathrm{P}$, suggested that for babies the retention ratio of $\mathrm{Ca}: \mathrm{P}$ should be $\mathrm{I} \cdot 5^{-I} \cdot 6$, on the assumption that one-quarter to one-third of the $\mathrm{P}$ retained was deposited in the soft tissues. The present results show that these deductions apply to babies receiving preparations made from cow's milk. The retention ratio for these babies was $1 \cdot 56$, and from calculations of amounts deposited in the skeleton it appeared that about one-third of the $\mathrm{P}$ retained was available for the growth and development of the soft tissues. The ratio of the amounts retained by the breast-fed babies, however, was much lower, and over one-half of the $\mathrm{P}$ must have been used in the development of the soft tissues. If breast milk is considered as the proper food for babies then Stearns's recommendations cannot be valid.

No figures are available for the $\mathrm{Mg}$ content of the skeleton at 6 months of age but, since most of the $\mathrm{Mg}$ in the body is combined with phosphate and carbonate in the skeleton, the high retention by bottle-fed babies supplies further evidence that the chemical maturation of the skeleton was progressing more rapidly in the bottle-fed babies than in the breast-fed babies.

\section{SUMMARY}

r. Retention of nitrogen and minerals by twenty-two normal full-term baby boys has been studied during the 6 th, 7 th and 8 th days after birth. Thirteen babies were fully breast-fed and nine had received since birth no food other than a proprietary cow's-milk mixture which contained more nitrogen, potassium, chloride, phosphorus, calcium and magnesium than the 'average' breast milk.

2. Both groups of babies absorbed $80-90 \%$ of the $\mathrm{N}$ in their food and retained approximately half. The bottle-fed babies retained $127 \mathrm{mg} / \mathrm{kg}$ day $\mathrm{N}$ more than the breast-fed babies; the concentration of urea in their blood was higher, but urea accounted for only a small proportion of the additional $\mathrm{N}$ retained.

3. The bottle-fed babies ingested, absorbed and retained more $\mathrm{K}$ and $\mathrm{P}$ than the breast-fed babies. The urinary excretion of $P$ by the breast-fed babies was negligible $(0.46 \mathrm{mg} / \mathrm{kg}$ day), whereas the bottle-fed babies excreted on average $34.9 \mathrm{mg} / \mathrm{kg}$ day in their urine.

4. The bottle-fed babies retained three to four times as much $\mathrm{Mg}$ and five times as much $\mathrm{Ca}$ as the breast-fed babies, but the urinary excretions of the babies having the cow's-milk preparations were significantly lower than the excretions of the babies having breast milk. 
5. The urinary excretions of $\mathrm{Ca}$ and $\mathrm{Mg}$ of breast-fed babies who had received oral supplements of $\mathrm{P}$ were less than those of the breast-fed babies who had received no supplement, and it seems possible that the small amount of $\mathbf{P}$ in breast milk limits the retention of $\mathrm{Ca}$ and $\mathrm{Mg}$.

6. It is suggested that the chemical maturation of the soft tissues and of the skeleton of babies receiving cow's-milk preparations proceeds faster than that of the tissues of breast-fed babies.

This investigation was made possible by a studentship awarded by Joseph Rank, Ltd. I am indebted to Dr D. Gairdner for allowing me to study babies under his care at the Maternity Hospital, Mill Road, Cambridge, to Miss E. Colbourn and Miss P. Hennessy for their help in the collection of the samples and to $\mathrm{Dr} N$. Hatemi for giving me samples of urine from nine breast-fed babies who had received phosphate supplements. I am very grateful to Dr Widdowson for her valuable help and encouragement throughout the work.

\section{REFERENCES}

Aitken, F. C. \& Hytten, F. E. (1960). Nutr. Abstr. Rev. 30, $34 \mathrm{r}$.

Association of Official Agricultural Chemists (r950). Official Methods of Analysis, 7th ed., p. 506. Washington: Association of Official Agricultural Chemists.

Atwater, W. O. \& Benedict, F. G. (1899). Bull. U.S. Off. Exp. Stas. 69, г12.

Benjamin, H. R., Gordon, H. H. \& Marples, E. (i943). Amer. F. Dis. Child. 65, 412.

Bunge, G. (1874). Z. Biol. 10, 295.

Dean, R. F. A. \& McCance, R. A. (1948). F. Physiol. 107, I82.

Dickerson, J. W. T. (1959). Proc. Nutr. Soc. r8, xxix.

Dickerson, J. W. T. \& Widdowson, E. M. (1960). Biochem. F. 74, 274.

Duckworth, J. \& Warnock, G. M. (1942-3). Nutr. Abstr. Rev. 12, 167.

Economou-Mavrou, C. \& McCance, R. A. (1958). Biochem. F. 68, 573 .

Fomon, S. J. \& May, C. D. (1958). Pediatrics, Springfield, 22, ror.

Frost, L. H. \& Jackson, R. L. (195I). F. Pediat. 39, 585.

Gamble, J. L., Wallace, W. M., Eliel, L., Holliday, M. A., Cushman, M., Appleton, J., Shenberg, A. \& Piotti, J. (195 I). Pediatrics, Springfield, 7, 305 .

Gardner, L. I., Maclachlan, E. A., Pick, W. D., Terry, M. L. \& Butler, A. M. (I950). Pediatrics, Springfield, $\mathbf{5}, 228$.

Gordon, H. H. \& Levine, S. Z. (1944). F. Pediat. 25, 464.

Hawk, P. B., Oser, B. L. \& Summerson, W. H. (1954). Practical Physiological Chemistry, 13th ed. London: J. and A. Churchill.

Hoffman, W. S., Parmelee, A. H. \& Grossman, A. (1949). Amer. F. Dis. Child. 77, 49.

Jeans, P. C. \& Stearns, G. (1933). Amer. F. Dis. Child. 46, 49.

Jeans, P. C., Stearns, G., McKinley, J. B., Goff, E. A. \& Stinger, G. (I936). F. Pediat. 8, 403.

King, E. J. (1946). Microanalysis in Medical Biochemistry. London: J. and A. Churchill.

Kramer, B. \& Tisdall, F. K. (r921). F. biol. Chem. 46, 339.

Lee, M. H. \& Widdowson, E. M. (1937). Biochem. F. 31, 2035.

Levin, B., Mackay, H. M. M., Neill, C. A., Oberholzer, U. G. \& Whitehead, T. P. (1959). Spec. Rep. Ser. med. Res. Coun., Lond., no. 296.

McCance, R. A. \& von Finck, M. A. (1947). Arch. Dis. Childh. 22, 200.

McCance, R. A. \& Shipp, L. H. (1933). Spec. Rep. Ser. med. Res. Coun., Lond., no. 187.

McCance, R. A. \& Widdowson, E. M. (1956). F. Physiol. r33, 373 .

McCance, R. A. \& Widdowson, E. M. (1958a). F. Physiol. r4r, 8I.

McCance, R. A. \& Widdowson, E. M. (1958b). F. Physiol. 141, 88.

Nelson, M. U. K. (1930). Amer. F. Dis. Child. 39, 701.

Rominger, E. \& Meyer, H. (1927). Arch. Kinderheilk. 80, 195.

Rominger, E. \& Meyer, H. (r93I). Z. Kinderheilk. 50, 509.

Smith, C. A. (1959). The Physiology of the Newborn Infant, 3rd ed. Springfield: C. C. Thomas.

Stearns, G. (1939). Physiol. Rev. I9, 4I5.

Swanson, W. W. \& Iob, L. U. (1933). Amer. F. Dis. Child. 45, 1036. 
Vol. 15

von Lieberman, L. \& Székely, S. (1898). Pflüg. Arch. ges. Physiol. 72, 360.

Widdowson, E. M. \& Dickerson, J. W. T. (1960). Biochem. F. 77, 30.

Widdowson, E. M., Dickerson, J. W. T. \& McCance, R. A. (1958). Biochem. 7. 69, 42 r.

Widdowson, E. M. \& McCance, R. A. (1959). Acta paediat. 48, 383 .

Widdowson, E. M., Slater, J. E., Harrison, G. E. \& Sutton, A. (1960). Lancet, ii, 941.

Widdowson, E. M. \& Southgate, D. A. T. (1959). Biochem. F. 72, 200.

Widdowson, E. M. \& Spray, C. M. (1951). Arch. Dis. Childh. 26, 205.

Wilmer, H. A. (1940). Proc. Soc. exp. Biol., N.Y., 43, 545. 